\title{
Failure Analysis of Woven Kevlar/Epoxy under Uniaxial Tension
}

\author{
Norzihan Rahimi ${ }^{1}$, Ahmad Kamil Hussain ${ }^{2 *}$, Mohd Sultan Ibrahim Shaik Dawood ${ }^{3}$, Adib Zulfadhli Mohd Alias ${ }^{4}$, \\ Muhamed Hafiy Afiq Md Yusoff ${ }^{5}$, Jamaluddin Mahmud \\ ${ }^{1}$ Faculty of Mechanical Engineering, Universiti Teknologi MARA, Shah Alam, Selangor, Malaysia \\ ${ }_{2}^{2}$ Department of Mechanical Engineering, International Islamic University Malaysia \\ *Corresponding author E-mail: ahmadkamil@salam.uitm.edu.my
}

\begin{abstract}
The increasing demand for newer materials with versatile properties such as high strength-to-weight ratio; has made fiber reinforced composite materials a favourable choice in various applications, particularly in the automotive, aerospace, marine, sports and defense industries. Moreover, the properties of a composite material could be tailored for specific functions or applications. Despite its many attractive features, composite material fails in a complex manner involving matrix failure, fiber failure and delamination. This failure behaviour needs to be well established. The objective of this study is to perform failure analysis on a woven Kevlar/Epoxy composite laminate subjected to uniaxial tension and establish its failure trend. The lamination sequence is $\left(\theta_{4} / 0_{4} /-\theta_{4}\right)_{\mathrm{S}}$ where the angle, $\theta$, ranges from $0^{\circ}$ to $90^{\circ}$. The failure analysis was carried out using a commercial finite element software, Ansys and comparisons were made using analytical methods (Matlab). The values of stresses were computed and Maximum Stress Theory was employed to check for failure. The trend of failure, in terms of the failure curves (normalized first ply failure and last ply failure loads), for woven Kevlar/Epoxy was established. This study had produced new failure datas for woven Kevlar/Epoxy and thus, contributes significant knowledge about the failure behaviour of composite materials.
\end{abstract}

Keywords: Kevlar/epoxy, composite laminate, failure analysis, Ansys, Matlab.

\section{Introduction}

Applications of composites have been expanded widely in various fields such as aircraft, sporting goods, automotive and in biomedical industries. Kevlar is one of the many kinds of fibers which has been used extensively due to its excellent mechanical properties, light weight, toughness, tensile strength, unique flexibility and resistance to impact damage [1][2]. Kevlar fiber hybridized with other synthetic fibers can improve the compressive strength and delamination strength of Kevlar composites [2][3].

Presently, either physical test or any advanced computational method could be used to evaluate the performance of a composite to withstand crucial loading. The drawbacks of physical experiments are repetitive tests need to be carried out as well as adequate number of samples need to be prepared [4]. Thus, it is a time and cost consuming process. Computational methods such as finite element analysis, FEA, eliminate the limitations associated with physical experiments. This has led to many composite related investigations to be conducted using FEA tools such as Ansys, LsDyna and Abacus. In 2016, Sukirmar has evaluated ballistic response of the Kevlar/epoxy laminates for different velocities, thickness, lay-up and orientations using finite element approach [5].

There are several failure criteria available to be used in failure analysis. In this study the Maximum Stress Theory was used. Failure in the composite material is considered when the stress in the principal axis exceeds the corresponding strength in that direction [4][6].

The objective of this study is to perform failure analysis on a woven Kevlar/Epoxy composite laminate, subjected to uniaxial ten- sion and establish its failure trend, using a commercially available finite element software and analytical method; and to compare the results obtained from the two approaches. This is novel as no similar study adapting this approach, has been reported before.

\section{Methodology}

Fig. 1 provides a flowchart detailing the methodology used in carrying out the intended investigation. The investigation includes two stages, i.e., the validation stage and failure analysis stage.

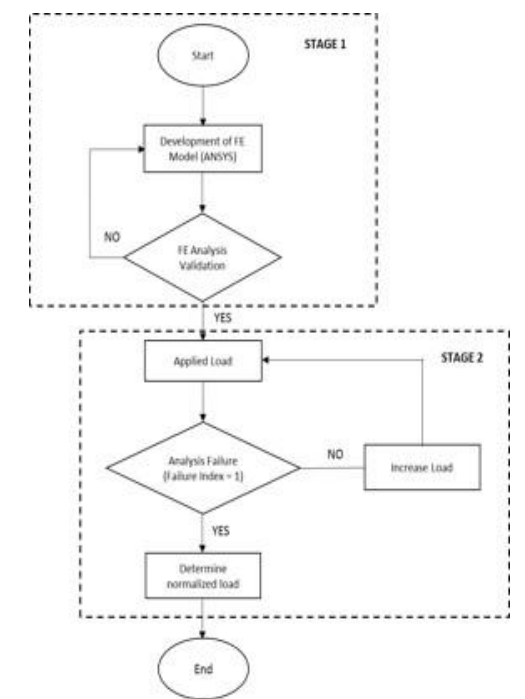

Fig. 1: Flowchart detailing the adopted methodology 


\section{Validation}

To prove that the current FE model and FE implementation is acceptable, the numerical validation procedure was performed first. In FE simulation, this initial stage is crucial before proceeding to the actual case study (the main objective of the current study). For the numerical validation purposes, an established case study conducted by other researchers [7][8] related to the current study was selected, where the current FE were compared to exact solutions [8]. Composite laminates made of Graphite/ Epoxy subjected to uniform transverse loads with several lamination schemes were modelled and simulated using a commercially available software, Ansys (v16.0 2014 SAS IP, Inc). The composite laminate geometry is shown in Fig. 2 and the material properties are shown in Table 1. $\mathrm{E}_{1}, \mathrm{E}_{2}, \mathrm{E}_{3}$ are referring to the Elastic Modulus in the principal directions 1,2 and 3 respectively. $v_{12}, v_{23}, v_{13}$ refer to the Poisson's ratio in the principal planes 12,23 and 13 respectively. $G_{12}, G_{23}, G_{13}$ refer to the Shear Modulus in the principal planes 12, 23 and 13 respectively. The composite laminate was meshed into 18 elements using eight-noded shell elements (shell 281). The laminate was simply supported and $0.1 \mathrm{psi}$ uniformly distributed load (UDL), $q_{o}$, was applied on top of the laminate in the transverse direction (negative $\mathrm{z}$-direction). The maximum deflection of these FE models were determined, recorded and compared to the exact solutions. The results from the FE solution are presented in Table 2 . The results clearly show that the current FE models and solutions are valid, where the errors are less than $1 \%$ for all lamination schemes.

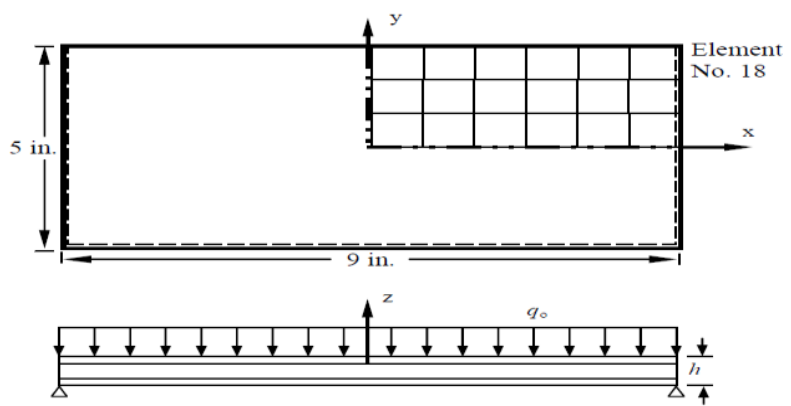

Fig. 2: Geometry of the composite laminate subjected to uniformly transverse load.

Table 1: Material properties of Graphite/Epoxy [8]

\begin{tabular}{|l|c|}
\hline \multicolumn{1}{|c|}{$\begin{array}{c}\text { Elastic } \\
\text { Parameters }\end{array}$} & Values \\
\hline $\mathrm{E}_{1}$ & $19.2 \times 10^{6} \mathrm{psi}$ \\
\hline $\mathrm{E}_{2}=\mathrm{E}_{3}$ & $1.56 \times 10^{6} \mathrm{psi}$ \\
\hline$v_{12}=v_{23}$ & 0.24 \\
\hline$v_{13}$ & 0.49 \\
\hline $\mathrm{G}_{12}=\mathrm{G}_{13}$ & $0.82 \times 10^{6} \mathrm{psi}$ \\
\hline $\mathrm{G}_{23}$ & $0.49 \times 10^{6} \mathrm{psi}$ \\
\hline Ply thickness, $h_{i}$ & $0.005 \mathrm{in} . / \mathrm{ply}$ \\
\hline
\end{tabular}

Table 2: Current FE solutions (maximum deflection, z-displacement) compared to exact solutions [8]

\begin{tabular}{|l|c|c|c|c|}
\hline $\begin{array}{l}\text { Lamination } \\
\text { scheme }\end{array}$ & $\begin{array}{c}\text { UDL } \\
\text { (psi) }\end{array}$ & $\begin{array}{c}\text { Exact } \\
\text { Solution (in.) }\end{array}$ & $\begin{array}{c}\text { ANSYS } \\
\text { (in.) }\end{array}$ & $\begin{array}{c}\text { Error } \\
\text { (\%) }\end{array}$ \\
\hline$[\mathbf{0 / 9 0 / 0 / 9 0 ]}$ & 0.1 & 0.134 & 0.135 & 0.75 \\
\hline$[\mathbf{0 / 9 0 / 9 0 / 0 ]}$ & 0.1 & 0.229 & 0.23 & 0.44 \\
\hline$[\mathbf{4 5 / - 4 5 / 4 5 / - 4 5 ]}$ & 0.1 & 0.1086 & 0.109 & 0.37 \\
\hline$[\mathbf{1 5 / - 1 5 / 1 5 / - 1 5}]$ & 0.1 & 0.2515 & 0.2519 & 0.16 \\
\hline$[\mathbf{4 5 5}-\mathbf{4 5}]$ & 0.1 & 1.6006 & 1.603 & 0.15 \\
\hline$[\mathbf{1 5}-/ 15]$ & 0.1 & 2.6039 & 2.607 & 0.12 \\
\hline
\end{tabular}

\section{Failure Analysis}

The objective of this study is to perform failure analysis on a woven Kevlar/Epoxy composite laminate subjected to uniaxial tension and establish its failure trend. Fig. 3 shows the typical loading and boundary conditions for a uniaxial tension model. Therefore, a square composite laminate with the dimensions of $20 \mathrm{~mm} \times 20 \mathrm{~mm}(a \times a)$ made of 24 layers of woven Kevlar/epoxy was considered. The composite laminate was arranged in the sequence of $\left(\theta_{4} / 0_{4} /-\theta_{4}\right)_{S}$ where the angle, $\theta$, ranges from $0^{\circ}$ to $90^{\circ}$. The material properties of a single lamina of woven Kevlar/epoxy are given in Table 3. As stated earlier in the previous section, $E_{1}$, $E_{2}, E_{3}$ are referring to the Elastic Modulus in the principal directions 1,2 and 3 respectively. $v_{12}, v_{23}, v_{13}$ refer to the Poisson's ratio in the principal planes 12,23 and 13 respectively. $G_{12}, G_{23}$, $\mathrm{G}_{13}$ refer to the Shear Modulus in the principal planes 12, 23 and 13 respectively. The strength of the Kevlar/epoxy lamina is denoted in Table 3 by $X_{T}$ and $X_{C}$, the strength of fiber in tension and compression respectively; by $\mathrm{Y}_{\mathrm{T}}$ and $\mathrm{Y}_{\mathrm{C}}$, the strength of matrix in tension and compression respectively; and $S$, its shear strength. An aspect ratio, $S=a / h=150$ was considered, and therefore the plate thickness, $h=0.133 \mathrm{~mm}$ with a cross sectional area of $2.666 \mathrm{~mm}^{2}$.

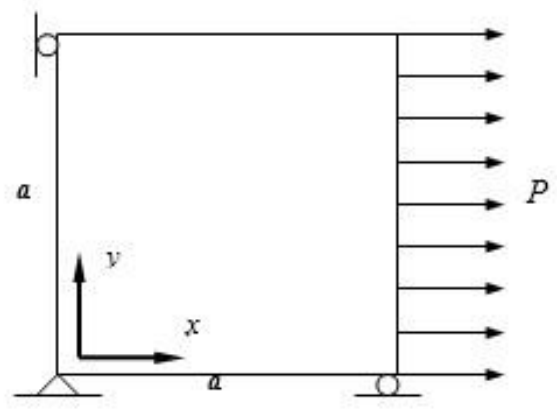

Fig. 3: Uniaxial tension model

Table 3: Material properties for woven Kevlar/epoxy [9]

\begin{tabular}{|l|c|}
\hline $\begin{array}{l}\text { Elastic \& Strength } \\
\text { parameters }\end{array}$ & Values \\
\hline $\mathrm{E}_{1}$ & $26.18 \mathrm{GPa}$ \\
\hline $\mathrm{E}_{2}=\mathrm{E}_{3}$ & $26.18 \mathrm{GPa}$ \\
\hline$v_{12}=v_{23}=v_{13}$ & 0.11 \\
\hline $\mathrm{G}_{12}=\mathrm{G}_{23}=\mathrm{G}_{13}$ & $1.53 \mathrm{GPa}$ \\
\hline $\mathrm{X}_{\mathrm{T}}$ & $420 \mathrm{MPa}$ \\
\hline $\mathrm{X}_{\mathrm{C}}$ & $150 \mathrm{MPa}$ \\
\hline $\mathrm{Y}_{\mathrm{T}}$ & $420 \mathrm{MPa}$ \\
\hline $\mathrm{Y}_{\mathrm{C}}$ & $150 \mathrm{MPa}$ \\
\hline $\mathrm{S}$ & $106 \mathrm{MPa}$ \\
\hline
\end{tabular}

For the element simulation, a commercially available software, ANSYS (v16.0 2014 SAS IP, Inc) was used. The Kevlar/epoxy composite laminate was meshed using eight-noded shell elements (shell 281). The boundary conditions for uniaxial tension model as shown in Fig. 3 was applied. When uniaxial tensile load, $P$ was applied, stresses induced into the laminate. Failure occurred when the applied load induced principal stresses greater than the lamina strength (fiber, matrix or shear strength). Therefore, for the FE failure analysis using Ansys, the failure predicted was based on the available built in failure theories and failure criteria available in Ansys, which is Maximum Stress Failure Criterion as shown in Eq. (1). In the general FE failure procedure, Ansys indicates the laminate failure when the failure index is 1 .

$\sigma_{1} \geq \mathrm{X}_{\mathrm{T}}$ or $\sigma_{1} \leq \mathrm{X}_{\mathrm{C}} ; \sigma_{2} \geq \mathrm{Y}_{\mathrm{T}}$ or $\sigma_{2} \leq \mathrm{Y}_{\mathrm{C}} ; \tau_{12} \geq \mathrm{S}$

In determining the first ply failure (FPF) load, the lowest load, $P$ that induced any first failure on the Kevlar/epoxy composite laminate was actually representing the FPF load. This load was recorded as FPF load. The procedure was repeated for all lamination scheme of $\left(\theta_{4} / 0_{4} /-\theta_{4}\right)_{S}$ as the angle $\theta$, increased in a step size of $10^{\circ}$ from $0^{\circ}$ to $90^{\circ}$. In determining the last ply failure (LPF) load, the lowest load, $P$ that induced the total (final) failure of the Kevlar/epoxy composite laminate, where all the layers failed, was actually representing the LPF load. This load was recorded as LPF 
load. And again, the procedure was repeated for all lamination scheme of $\left(\theta_{4} / 0_{4} /-\theta_{4}\right)_{\mathrm{S}}$ as the angle $\theta$, increased in a step size of $10^{\circ}$ from $0^{\circ}$ to $90^{\circ}$.

For comparison, analytical method was also adopted to compute the strains and stresses (global and principal) for the Kevlar/epoxy composite laminate due to the uniaxial tensile load applied on it. The strains and stresses computation was based on the general mechanics of materials approach involving equations such as Eq 2 to Eq. 10 in Appendix 1. Due to the size of the matrix calculation, as well as complexity in solving the mathematical equations, a Matlab programme was written to aid the computation. For the failure analysis, when the load increased, the stresses value increased. Similar to the FE simulation, Maximum Stress Failure Criterion (Eq. 1) was employed to predict the failure of the Kevlar/epoxy composite laminate. The FPF load and LPF load were determined, recorded and used as reference for the comparison between FE simulation and analytical method.

\section{Results and Discussion}

The sample outputs from the Ansys simulation is shown in Fig. 4. The sample outputs from the Matlab programme is shown in Fig. 5. In general, both figures display the failure index computed by both methods, FE simulation and analytical method. It is obvious to see that the main advantage of using a FE software is that it provides visualisation. The laminate deformation could be viewed instantly. However, the outputs from the Matlab programme are basically a table of numbers. Nevertheless, it is much better than computing the stresses of a laminate using hand calculation (without the aid of a programme).
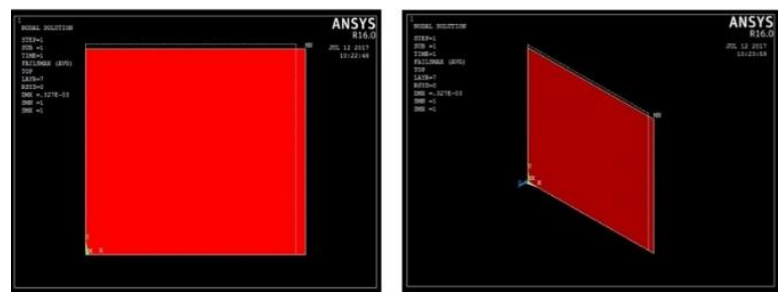

Fig. 4: Sample outputs of failure index (Ansys)

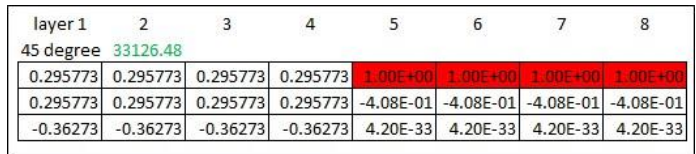

Fig. 5: Sample outputs of failure index (Matlab)

The results of the first ply failure and last ply failure are shown in Table 4 and Table 5 respectively. The tables compare the results obtained from Ansys and Matlab for the respective cases. From the tables it can be seen that the results from Ansys and Matlab conform well to each other.

Table 4: First ply failure

\begin{tabular}{lllllll} 
Angle & \multicolumn{3}{c}{ Ansys } & & \multicolumn{2}{c}{ Analytical Method } \\
\hline \multicolumn{3}{c}{ First Ply failure } & & \multicolumn{2}{l}{ First Ply failure } \\
\hline $0^{\circ}$ & Line load & Load & Stress (MPa) & Line load & Load & Stress (MPa) \\
$10^{\circ}$ & 54033.05 & 1119.989 & 419.991 & 55999.44 & 1119.989 & 419.991 \\
$15^{\circ}$ & 51623.00 & 1032.661 & 405.243 & 54033.44 & 1080.669 & 405.245 \\
$20^{\circ}$ & 48376.17 & 967.523 & 387.168 & 51622.46 & 1032.449 & 387.160 \\
$30^{\circ}$ & 40434.10 & 808.682 & 303.817 & 48514.02 & 970.2803 & 363.850 \\
$40^{\circ}$ & 31109.03 & 622.180 & 233.315 & 40434.26 & 808.6852 & 303.253 \\
$45^{\circ}$ & 28964.80 & 579.296 & 217.233 & 33126.48 & 662.5296 & 248.445 \\
$50^{\circ}$ & 31109.00 & 622.180 & 233.315 & 34118.98 & 682.3796 & 255.889 \\
$60^{\circ}$ & 40433.85 & 808.677 & 303.250 & 40434.27 & 808.6853 & 303.253 \\
$70^{\circ}$ & 48376.20 & 967.524 & 362.817 & 48514.01 & 970.2802 & 363.850 \\
$75^{\circ}$ & 51622.08 & 1032.442 & 387.161 & 51622.46 & 1032.449 & 387.163 \\
$80^{\circ}$ & 54023.04 & 1080.461 & 405.168 & 54148.00 & 1082.960 & 406.104 \\
$90^{\circ}$ & 55999.46 & 1119.989 & 419.991 & 55999.83 & 1119.997 & 419.993 \\
\hline
\end{tabular}

Table 5: Last ply failure

\begin{tabular}{lllllll} 
Angle & \multicolumn{3}{c}{ Ansys } & \multicolumn{3}{c}{ Last Ply failure } \\
\hline \multicolumn{3}{c}{ Last Ply failure } & \multicolumn{3}{c}{ Analytical Method } \\
\hline & Line load & Load & Stress (MPa) & Line load & Load & Stress (MPa) \\
\hline $0^{\circ}$ & 55999.44 & 1119.989 & 419.991 & 55999.44 & 1119.989 & 419.990 \\
$10^{\circ}$ & 55773.85 & 1115.477 & 418.297 & 55772.44 & 1115.449 & 418.288 \\
$15^{\circ}$ & 55640.65 & 1112.813 & 417.300 & 55640.65 & 1112.813 & 417.299 \\
$20^{\circ}$ & 55790.78 & 1115.816 & 418.426 & 55791.12 & 1115.822 & 418.428 \\
$30^{\circ}$ & 59417.11 & 1188.342 & 445.623 & 59417.71 & 1188.354 & 445.627 \\
$40^{\circ}$ & 80175.44 & 1603.509 & 684.930 & 80179.60 & 1603.592 & 601.339 \\
$45^{\circ}$ & 91325.17 & 1826.503 & 684.930 & 112007.2 & 2240.144 & 840.043 \\
$50^{\circ}$ & 80175.37 & 1603.507 & 601.308 & 80179.60 & 1603.592 & 601.339 \\
$60^{\circ}$ & 59417.14 & 1188.343 & 445.623 & 59417.71 & 1188.354 & 445.627 \\
$70^{\circ}$ & 55790.82 & 1115.816 & 418.426 & 55791.12 & 1115.822 & 418.428 \\
$75^{\circ}$ & 55640.77 & 1112.816 & 417.301 & 55642.10 & 1112.842 & 417.310 \\
$80^{\circ}$ & 55773.87 & 1115.477 & 418.299 & 55772.44 & 1115.449 & 418.288 \\
$90^{\circ}$ & 55999.46 & 1119.989 & 419.991 & 55997.31 & 1119.946 & 419.974 \\
\hline
\end{tabular}

A plot comparing the first and last ply failure is provided in Fig. 6 which compares the effect of ply angle on the failure stress. The pattern of failure is different for the first and last ply failure. In the case of first ply failure it can be seen that the failure stress reduces with respect to the ply angle up to $45^{\circ}$ after which there is an observed symmetry. Whereas, in the case of last ply failure, the failure stresses are higher in comparison to first ply failure and there is also an observed symmetry at $45^{\circ}$. However, in the case of last ply failure, it is noticed that the for ply angles between $0^{\circ}$ to $15^{\circ}$ there is a slight drop in the failure stress values and beyond $15^{\circ}$ the values increase until ply angle of $45^{\circ}$. From the plot it can be seen that the highest and lowest maximum stress that can be withstood by composite woven Kevlar/epoxy is $684.930 \mathrm{MPa}$ at ply angle of $45^{\circ}$ and $417.3 \mathrm{MPa}$ at ply angle of $15^{\circ}$ for the last ply failure. For the first ply failure, the highest and lowest maximum stress values that can be withstood by composite woven Kevlar/epoxy are 419.991 MPa at ply angle of $45^{\circ}$ and $217.233 \mathrm{MPa}$ at ply angle of $15^{\circ}$.

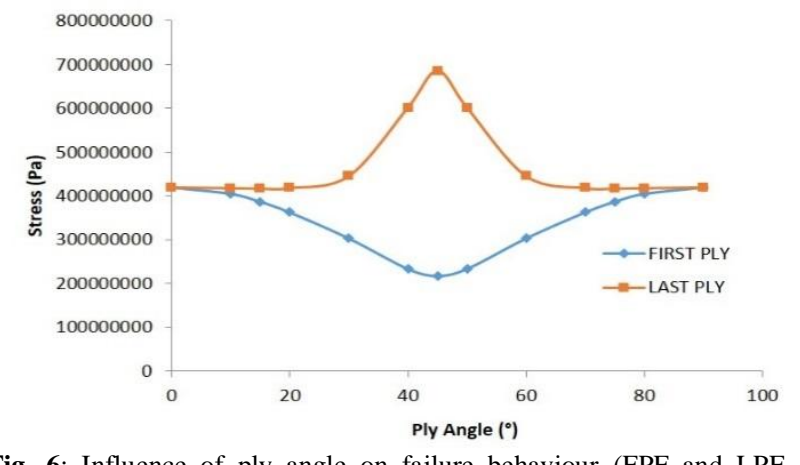

Fig. 6: Influence of ply angle on failure behaviour (FPF and LPF curves) of woven Kevlar/epoxy using Ansys

From the analysis conducted using Ansys, it was also observed that the composite plate stretched under the applied load. Figs. 7 and 8 show the observed elongation for $45^{\circ}$ ply angle for first and last ply failure respectively. The [A] [B] and [D] matrixes for $45^{\circ}$ and $0^{\circ}$ provided in Table 6 and 7 justify the observation made. In both the tables it can be seen that the coupling term [B] and bending term $[D]$ are very small in comparison to the extensional term [A].
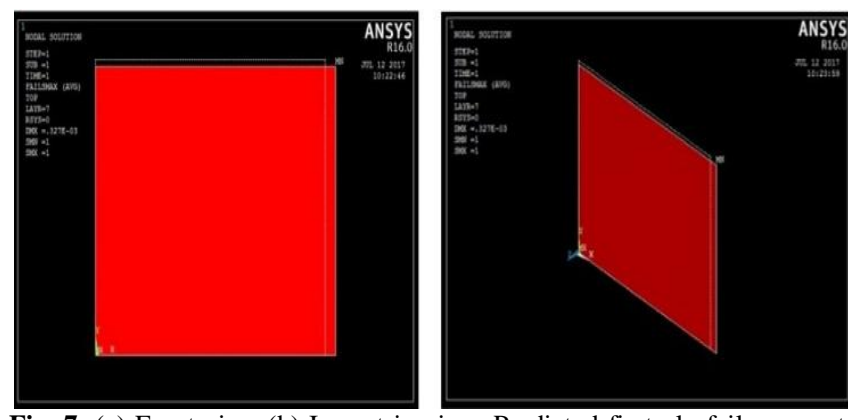

Fig. 7: (a) Front view (b) Isometric view. Predicted first ply failure on at ply angle of $45^{\circ}$ 

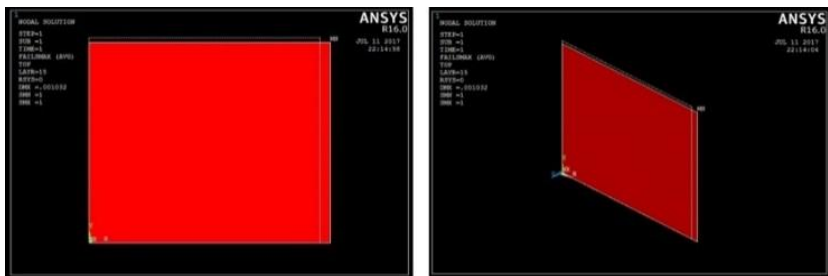

Fig. 8: (a) Front view (b) Isometric view. Predicted last ply failure on a ply angle of $45^{\circ}$

Table 6: $[\mathrm{A}],[\mathrm{B}]$, and [D] matrix obtained from Ansys for $45^{\circ}$

\begin{tabular}{|c|c|c|c|}
\hline \multicolumn{4}{|c|}{ First Ply Failure and Last Ply Failure } \\
\hline \multicolumn{4}{|c|}{ Angle $45^{\circ}$} \\
\hline$[\mathrm{A}]=$ & $\begin{array}{l}0.262141 E+07 \\
0.130064 E+07 \\
0.282728 E-26-\end{array}$ & $\begin{array}{r}0.130064 E+07- \\
0.262141 E+07 \\
-0.282728 E-26\end{array}$ & $\begin{array}{r}-0.605845 E-27 \\
0.605845 E-27 \\
0.111637 E+07\end{array}$ \\
\hline$[B]=$ & $\begin{array}{l}0.310862 \mathrm{E}-13 \\
0.183187 \mathrm{E}-13 \\
0.825839 \mathrm{E}-30\end{array}$ & $\begin{array}{r}0.183187 \mathrm{E}-13- \\
0.310862 \mathrm{E}-13 \\
-0.825839 \mathrm{E}-30\end{array}$ & $\begin{array}{r}-0.175029 \mathrm{E}-29 \\
0.175029 \mathrm{E}-29 \\
0.186517 \mathrm{E}-13\end{array}$ \\
\hline$[\mathrm{D}]=$ & $\begin{array}{l}0.373338 \mathrm{E}-02 \\
0.207696 \mathrm{E}-02 \\
0.457508 \mathrm{E}-18\end{array}$ & $\begin{array}{r}0.207696 \mathrm{E}-02 \\
0.373338 \mathrm{E}-02 \\
-0.457508 \mathrm{E}-18\end{array}$ & $\begin{array}{r}0.206342 E-18 \\
-0.206342 E-18 \\
0.180396 E-02\end{array}$ \\
\hline \multicolumn{4}{|c|}{ Table 7: $[A],[B]$, and $[D]$ matrix obtained from Ansys for 0} \\
\hline \multicolumn{4}{|c|}{$\begin{array}{l}\text { First Ply Failure and Last Ply Failure } \\
\end{array}$} \\
\hline \multicolumn{4}{|c|}{ Angle $0^{\circ}$} \\
\hline$[A]=$ & $\begin{array}{l}0.353339 E+07 \\
388672 . \\
0.00000\end{array}$ & $\begin{array}{l}388672 . \\
0.353339 E+07 \\
0.00000\end{array}$ & $\begin{array}{l}0.00000 \\
0.00000 \\
204398 .\end{array}$ \\
\hline$[B]=$ & $\begin{array}{l}0.723865 E-13 \\
0.455191 E-14 \\
0.00000\end{array}$ & $\begin{array}{l}0.455191 E-14 \\
0.723865 E-13 \\
0.00000\end{array}$ & $\begin{array}{l}0.00000 \\
0.00000 \\
0.408007 E-14\end{array}$ \\
\hline$[D]=$ & $\begin{array}{l}0.523454 \mathrm{E}-02 \\
0.575799 \mathrm{E}-03 \\
0.00000\end{array}$ & $\begin{array}{l}0.575799 E-03 \\
0.523454 E-02 \\
0.00000\end{array}$ & $\begin{array}{l}0.00000 \\
0.00000 \\
0.302806 E-03\end{array}$ \\
\hline
\end{tabular}

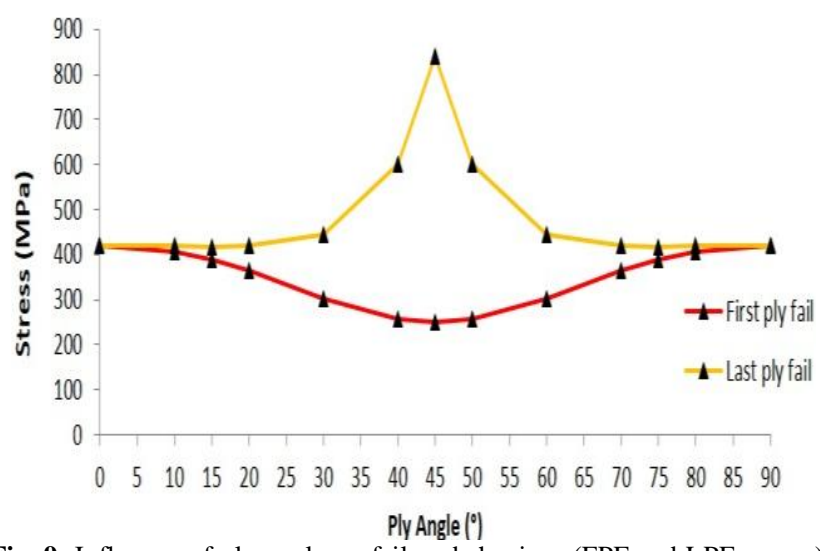

Fig. 9: Influence of ply angle on failure behaviour (FPF and LPF curves) of woven Kevlar/epoxy calculated using Matlab

Fig. 9 shows the results of calculated failure stress values against the ply angle on the first ply failure and last ply failure using Matlab. The trend of the results is the same as to that obtained using Ansys. For the first ply failure the stress values decrease with the increase in the ply angles and there is an observed symmetry at $45^{\circ}$. In the case of last ply failure, the stress values increase with increasing ply angles. From the plots it can be seen that ply angle $45^{\circ}$ offers best resistance to complete failure as the failure stress required is about $840 \mathrm{MPa}$. This is due to the fact that woven composites will retain more stress to break at the last ply at ply angle of $45^{\circ}$. The calculated reduced stiffness [Q], transformed reduced stiffness $[\overline{\boldsymbol{Q}}]$ and $[\mathrm{A}],[\mathrm{B}],[\mathrm{D}]$ coefficients are shown in Table 8 . From the table it can be seen that the calculated values of $[\mathrm{A}],[\mathrm{B}],[\mathrm{D}]$ coefficients are similar to that obtained from Ansys.
Table 8: $[\mathrm{Q}],[\bar{Q}],[\mathrm{A}],[\mathrm{B}]$, and [D] matrix calculated using Matlab

\begin{tabular}{|c|c|c|c|c|c|c|}
\hline \multirow{2}{*}{$\begin{array}{l}\text { Angle } \\
Q_{11}\end{array}$} & \multirow{2}{*}{$\begin{array}{l}0^{\circ} \\
2.65 \mathrm{E}+10\end{array}$} & \multirow{2}{*}{$\frac{45^{\circ}}{2.65 \mathrm{E}+10}$} & \multicolumn{4}{|c|}{ First Ply fail and Last Ply fail } \\
\hline & & & \multirow{4}{*}{ [A] } & \multirow{2}{*}{\multicolumn{2}{|c|}{$\begin{array}{cc}\text { Angle } & 0^{\circ} \\
3533411.17 & 388675.2\end{array}$}} & \multirow{2}{*}{$\begin{array}{l}0 \\
0\end{array}$} \\
\hline$Q_{12}$ & $2.92 E+09$ & $2.92 E+09$ & & & & \\
\hline$Q_{22}$ & $2.65 E+10$ & $2.65 E+10$ & & 388675.228 & 3533411 & 0 \\
\hline$Q_{16}$ & 0 & & & 0 & 0 & 204399.4 \\
\hline & & & & 0 & 0 & \\
\hline$Q_{26}$ & 0 & 0 & [B] & 0 & 0 & 0 \\
\hline$Q_{66}$ & $1.53 \mathrm{E}+09$ & $1.53 \mathrm{E}+09$ & & 0 & 0 & 0 \\
\hline \multirow[t]{2}{*}{$\overline{Q_{11}}$} & $2.65 \mathrm{E}+10$ & 1st layer $=1.62 \mathrm{E}+10$ & & & & \\
\hline & & $5^{\text {th }}$ layer $=2.65 \mathrm{E}+10$ & [D] & $\begin{array}{l}0.00523465 \\
0.00057581\end{array}$ & $\begin{array}{l}0.000576 \\
0.005235\end{array}$ & $\begin{array}{l}0 \\
0\end{array}$ \\
\hline \multirow[t]{2}{*}{$\overline{Q_{12}}$} & $2.92 E+09$ & 1st layer $=1.32 \mathrm{E}+10$ & & 0 & 0 & 0.000303 \\
\hline & & $\begin{array}{l}5^{\text {th }} \text { layer }=2.92 \mathrm{E}+09 \\
1 \text { st layer }=1.91 \mathrm{E}-06\end{array}$ & & Angle & $45^{\circ}$ & \\
\hline \multirow{2}{*}{$\overline{Q_{16}}$} & 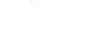 & $5^{\text {th }}$ layer $=0$ & [A] & 2621432.14 & 1300654 & $-1.29 \mathrm{E}-26$ \\
\hline & & & 西 & 1300654.26 & 2621432 & $1.29 \mathrm{E}-26$ \\
\hline \multirow[t]{2}{*}{$\overline{Q_{22}}$} & $2.65 E+10$ & 1st layer $=1.62 \mathrm{E}+10$ & & $-1.29 \mathrm{E}-26$ & $1.29 \mathrm{E}-26$ & 1116378 \\
\hline & & $5^{\text {th }}$ layer $=2.6501 \mathrm{E}+10$ & & $2.66 \mathrm{E}-15$ & $-4.44 E-15$ & 0 \\
\hline \multirow[t]{2}{*}{$\overline{Q_{26}}$} & - & $1 \mathrm{st}$ layer $=-1.91 \mathrm{E}-06$ & {$[\mathrm{~B}]$} & $-4.44 E-15$ & 2.66E-15 & 0 \\
\hline & & $5^{\text {th }}$ layer $=0$ & & & & $-8.88 E-16$ \\
\hline \multirow[t]{2}{*}{$\overline{Q_{66}}$} & $1.53 E+09$ & 1st layer $=1.18 \mathrm{E}+10$ & [D] & 0.00373346 & 0.002077 & $2.51 \mathrm{E}-19$ \\
\hline & & $5^{\text {th }}$ layer $=1.53 \mathrm{E}+09$ & & 0.002071 & 0.003733 & $-2.51 \mathrm{E}-19$ \\
\hline
\end{tabular}

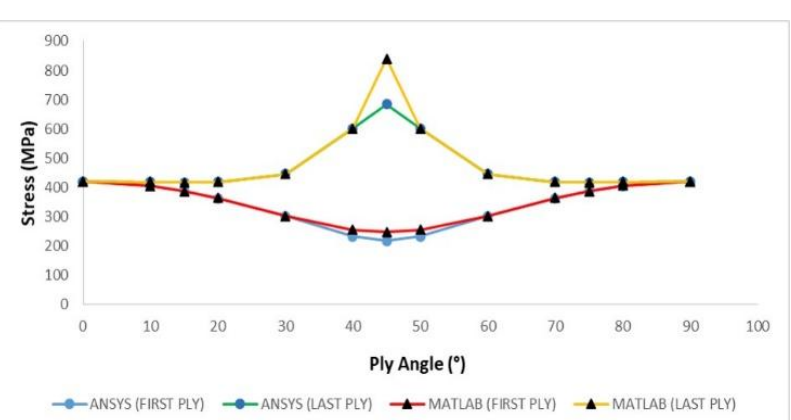

Fig. 10: Comparison of results obtained from Ansys and Matlab: influence of ply angle on FPF and LPF curves

Lastly, the results obtained by Ansys and Matlab are compared in Fig. 10. The failure stress values for first ply failure between that obtained from Ansys and Matlab are very close to each other. A maximum difference in results for the first ply failure between the two models occurs at ply angle of $45^{\circ}$ for which the difference is about $12.6 \%$. In the case of last ply failure the difference is much higher which is at $18.5 \%$ for $45^{\circ}$ ply angle. The differences in the results can be attributed to mesh sensitivity and element type used for those obtained using Ansys.

\section{Conclusion}

This paper reports on the failure analysis of woven Kevlar/epoxy laminate subjected to uniaxial tension using Ansys and Matlab. The corresponding failure trend has also been highlighted. Results from both simulations were successfully obtained and discussed. The failure was predicted based on Maximum Stress Theory. It was found that the failure stress values obtained using Ansys were generally similar to that obtained using Matlab. Though a maximum difference of $18 \%$ was observed in the case of last ply failure at $45^{\circ}$ ply angle, this discrepancy could be due to mesh sensitivity for the results obtained using Ansys. As conclusion, the analytical model offers a simplistic approach to model and predict failure which can give significant insight to the understanding of the failure mechanism of simple composite models such as the one considered in the present study.

\section{Acknowledgement}

This work is supported by the Ministry of Education (MOE) Malaysia and Universiti Teknologi MARA (Fundamental Research Grant Scheme, grant no 600 - RMI/FRGS 5/3 (80/2014)). 


\section{References}

Yang S, Chalivendra VB \& Kim YK (2017), Fracture and impact characterization of novel auxetic Kevlar/Epoxy laminated composites. Composite Structures, vol. 168, pp. 120-129.

Singh TJ \& Samanta S (2015), Characterization of Kevlar Fiber and Its Composites: A Review, Mater. Today Proc., vol. 2, no. 4 5, pp. 1381-1387.

Bandaru AK, Patel S, Sachan Y, Ahmad S, Alagirusamy R \& Bhatnagar N (2016), Mechanical behavior of Kevlar/basalt reinforced polypropylene composites, Compos. Part A Appl. Sci. Manuf., vol. 90, pp. 642-652.

Noh NN, Samsudin AH \& Mahmud J (2017), Failure Analysis of Glass/Epoxy and Graphite/Epoxy Laminates due to the Effect of Variation in Lamination Scheme and Angle of Fibre Orientation. Materials Science Forum, vol. 889, pp. 36-44.

Sikarwar RS, Rajput NS, Velmurugan R \& Naik S (2017), FE Analysis of Impact on Kevlar/Epoxy Laminates with Different Orientations and Thicknesses. Mater. Today Proc., vol. 4, no. 2, pp. 2599-2607.

Rahimi N, Hussain AK, Meon MS \& Mahmud J (2012), Capability Assessment of Finite Element Software in Predicting the Last Ply Failure of Composite Laminates. Procedia Engineering 41, 1647-1653.

Rahimi N, Musa M, Hussain AK \& Mahmud J (2012), Finite Element Implementations to Predict the Failure of Composite Laminates under Uniaxial Tension. Advanced Materials Research, Vol. 499, pp 20-24.

Mahmud J, AF Ismail AF \& Pervez T (2005), Employing a failure criterion with interaction terms to simulate the progressive failure of carbon-epoxy laminates, IEM Journal, vol. 66(2), pp 6-14.

Icten BM, Karakuzu R \& Toygar ME (2006), Failure analysis of woven kevlar fiber reinforced epoxy composites pinned joints, Composite Structures, vol. 73, pp 443-450.

\section{Appendix 1}

The reduced stiffness formula and transformed reduced stiffness (due to angle variation) were calculated using the equations below:

\section{Reduced Stiffness Formula}

$$
\begin{aligned}
Q_{11} & =\frac{E_{1}}{1-V_{12} V_{21}} \\
Q_{12} & =\frac{V_{12} E_{2}}{1-V_{12} V_{21}} \\
Q_{22} & =\frac{E_{2}}{1-V_{12} V_{21}} \\
Q_{66} & =G_{12}
\end{aligned}
$$

Transformed reduced stiffness formula

$$
\begin{aligned}
& \overline{Q_{11}}=Q_{11} * \mathrm{~m}^{\wedge} 4+2 *\left(Q_{12}+2 * Q_{66}\right) * \mathrm{~m}^{\wedge} 2 * \mathrm{n}^{\wedge} 2+Q_{22} * \mathrm{n}^{\wedge} 4 \\
& \overline{Q_{12}}=\left(Q_{11}+Q_{22}-4 * Q_{66}\right) * \mathrm{~m}^{\wedge} 2 * \mathrm{n}^{\wedge} 2+Q_{12} *\left(\mathrm{~m}^{\wedge} 4+\mathrm{n}^{\wedge} 4\right) \\
& \overline{Q_{22}}=Q_{11} * \mathrm{n}^{\wedge} 4+2 *\left(Q_{12}+2 * Q_{66}\right) * \mathrm{~m}^{\wedge} 2 * \mathrm{n}^{\wedge} 2+Q_{22} * \mathrm{~m}^{\wedge} 4 \\
& \overline{Q_{16}}=\left(\left(Q_{11}-Q_{12}-\left(2 * Q_{66}\right)\right)^{*} \mathrm{n}^{*} \mathrm{~m}^{\wedge} 3\right)+\left(\left(Q_{12}-Q_{22}+\right.\right. \\
& \left.\left.\left(2 * Q_{66}\right)\right)^{*} \mathrm{n}^{\wedge} 3 * \mathrm{~m}\right) \\
& \overline{Q_{16}}=\left(\left(Q_{11}-Q_{12}-\left(2 * Q_{66}\right)\right)^{*} \mathrm{n}^{*} \mathrm{~m}^{\wedge} 3\right)+\left(\left(Q_{12}-Q_{22}+\right.\right. \\
& \left.\left.\left(2 * Q_{66}\right)\right)^{*} \mathrm{n}^{\wedge} 3 * \mathrm{~m}\right) \\
& \overline{Q_{16}}=\left(\left(Q_{11}-Q_{12}-\left(2 * Q_{66}\right)\right)^{*} \mathrm{n}^{*} \mathrm{~m}^{\wedge} 3\right)+\left(\left(Q_{12}-Q_{22}+\right.\right. \\
& \left.\left.\left(2 * Q_{66}\right)\right)^{*} \mathrm{n}^{\wedge} 3 * \mathrm{~m}\right)
\end{aligned}
$$

where:

$\mathrm{m}=\cos \theta$ and $\mathrm{n}=\sin \theta$ 